School of Finance

University of St.Gallen

REAL EFFECTS OF INVESTMENT BANKING RELATIONSHIPS: EVIDENCE FROM THE FINANCIAL CRISIS

DAVID OESCH

DUSTIN SCHUETTE

INGO WALTER

WORKING PAPERS ON FinANCE No. 2014/5

SWISS INSTITUTE OF BANKING AND FINANCE (S/BF - HSG)

FEBRUARY 2014

THIS VERSION: AUGUST 2015 


\title{
Real Effects of Investment Banking Relationships: Evidence from the Financial Crisis $^{* \dagger}$
}

\author{
David Oesch, ${ }^{\mathrm{a}}$ Dustin Schuette ${ }^{\mathrm{b}}$ and Ingo Walter ${ }^{\mathrm{c}}$ \\ ${ }^{\mathrm{a}}$ Department of Business Administration, University of Zurich \\ ${ }^{\mathrm{b}}$ Accenture Strategy, Zurich \\ ${ }^{c}$ Department of Finance, Stern School of Business, New York University \\ This Version: August 2015
}

\begin{abstract}
We investigate the damage to real-sector investment spending and corporate financing activities triggered by the failure of three major investment banks during the 2007-09 financial crisis. We find that corporations characterized by pre-crisis corporate investment banking relationships with troubled investment banks exhibit significantly lower post-crisis investment spending activity and securities issuance compared to corporations that were not affiliated with the troubled institutions. The effect varies systematically with the nature and strength of the investment banking relationship. Our results are robust with respect to various modifications and extensions of our empirical design (including a matched control sample) and generally inconsistent with alternative explanations unrelated to investment banking relationships.
\end{abstract}

JEL Classification: C78, G24, G32, L14

Keywords: firm-underwriter relationship, investment banking, financial crisis, financial shocks, real effects, investment, financing, cash holdings.

\footnotetext{
* We are grateful to Yakov Amihud, Manuel Ammann, Patrick Bolton, Jens Jackwerth, Karolin Kirschenmann, Alexander Ljungqvist, Bill Megginson, Anthony Saunders, Markus Schmid and Rene Stulz as well as seminar participants at the University of St. Gallen and at the 2014 IBEFA meetings in Philadelphia for valuable suggestions.

$\dagger$ Address for correspondence: David Oesch, University of Zurich, Department of Business Administration, Plattenstrasse 14, CH-8032 Zurich. Phone +41 4463428 01. Fax +41 4463449 12. e-mail: david.oesch@business.uzh..
} 


\section{Introduction}

Do relationships between nonfinancial corporations and investment banks have a significant impact on nonfinancial corporations' capital spending and financing activities? Research so far has provided little evidence on this question, due in part to problems in observing and measuring such relationships. The issue has gained in importance in light of the ongoing restructuring of the global investment banking industry as new regulations take hold and impact investment banking relationships with corporate clients in the wake of the financial crisis of 2007-2009.

During 2008, three major financial firms with investment banking operations either failed (Lehman Brothers) or had to be taken over (Bear Stearns, Merrill Lynch). ${ }^{1}$ Table 1 provides an overview of the respective underwriting market shares of these three firms during the ten years prior to the financial crisis. Using data from the SDC New Issues database on U.S. issues underwritten between 1998 and 2008, the table indicates that the market share of the underwriters that disappeared in 2008 was substantial. Over this ten-year period, one of these three firms served as lead underwriter in roughly 25 percent of deals covered by the data.

In this paper, we analyze the disruption of underwriter relationships experienced by clients of the three aforementioned firms (hereafter "investment banks") to investigate whether a negative shock to these relationships affected corporate clients' capital expenditure and financing activities. We believe this empirical setting is particularly appropriate for an analysis of the effects of investment banking relationships because (in contrast to cross-sectional regressions correlating measures of underwriter relationship strength with corporate outcomes) it represents

\footnotetext{
${ }^{1}$ For purposes of this paper, investment banking during the period covered by our study is defined as underwriting and dealing in fixed-income and equity securities and their derivatives, proprietary investments, and advisory mandates related to mergers and acquisitions, corporate restructurings and complementary financial and advisory activities.
} 
a possible exogenous distortion of underwriter relationships introduced by the failure or nearfailure of investment banks during the financial crisis.

Previous literature shows that investment banking relationships provide economic value. This appears to be associated with economies of scale and scope (James, 1992; Drucker and Puri, 2005), switching costs (Burch, Nanda and Warther, 2005), monitoring (Hansen and Torregrosa, 1992), or admission to an established investor network (Gao and Ritter, 2010).

Kovner (2012) and Fernando, May and Megginson (2012) provide empirical evidence that the economic value of investment banking activities is shared with client firms. Using stock market reactions to the failure of troubled investment banks, the authors suggest that market participants perceive these relationships to be relevant for firm value. Specifically, they document that the shares of clients of troubled investment banks experienced significantly negative abnormal returns around the dates when the investment banks' problems became public compared to firms without such adversely affected relationships.

Here we attempt to answer the question whether the disruption of underwriter relationships following the demise or merger/takeover of a company's underwriter affects client firms' investment spending and financing activities. We provide evidence that this is indeed the case.

Using a difference-in-differences approach that contrasts changes in investment spending and financing of clients of troubled underwriters to clients of other investment banks, we document that firms which mandated a troubled investment bank as lead underwriter of a capital issue in the three years prior to September 2008 (our treatment sample) experienced a reduction in investment spending and financing that was on average $6.3 \%$ and $12.4 \%$, respectively, larger than for control firms. Moreover, our results show that corporate clients alter their financing mix 
to use sources of capital that are less information-sensitive such as internal financing, leading to a reduction in cash holdings.

We interpret these results as consistent with a certification effect of investment banking relationships as documented by Megginson and Weiss (1991), suggesting that one possible benefit of a relationship with an investment bank is the attestation that it provides about the quality of clients' investment projects. Disruptions to such relationships (and the certification function provided by them) could in turn increase the firm's cost of capital, decrease investment spending and render capital expenditure more sensitive to the availability of internal funds. Consequently, firms may reduce their investment spending and substitute away from external capital to internal funding.

The effects that we document in this paper vary systematically with the nature of the established investment banking relationships. Companies maintaining an equity underwriting relationship with a troubled investment bank experience stronger effects, reflected especially in a reduction in equity financing. Companies with a debt underwriting relationship with a troubled investment bank, on the other hand, experience a particularly strong reduction in debt financing and a much weaker effect on equity financing. For example, client firms that had established relationships on the basis of equity issuance experienced a change in equity issuance that was $13.1 \%$ smaller compared to control firms. In contrast, we find firms whose relationship with a troubled investment bank originates from debt issuance to be negatively affected in the subsequent volume of debt issuance, while there is no significant effect in their subsequent activity in equity issuance.

We perform a number of robustness tests that rule out alternative explanations and mitigate concerns that our results are driven by factors unrelated to investment banking 
relationships. Specifically, we show that our documented treatment effect decreases with the strength of the investment banking relationship as measured by the amount of time elapsed since the troubled investment bank was last mandated as lead underwriter. This finding is considerably more difficult to reconcile with explanations other than established investment banking relationships. We augment our basic difference-in-differences research design by a matched sample estimator and show that our results are not driven by differences between treated and control firms. Our treatment effect also does not seem to be driven by unobservable firm characteristics unrelated to investment banking relationships, such as lending. In this regard, we screen all SEC filings by control companies and reduce the control sample to firms with contractual exposure to the troubled investment banks. The difference-in-differences estimations using this alternative control sample are effectively unchanged compared to our baseline case.

Next, we provide evidence that our results are somewhat different for (but not exclusively driven by) clients of Lehman Brothers, alone among the three troubled investment banks that actually filed for protection under Chapter 11 of the US Bankruptcy Code.

Moreover, our findings seem to be unrelated to the fact that the troubled firms ranked among the largest investment banks prior to 2008. When we reduce the control sample to clients of investment banks with similar status in 2007, our results remain virtually unchanged. In further tests, we control for potentially different levels of firm risk in the treatment and control group. Specifically, we are able to rule out the alternative explanation that our results are based on significantly higher levels of firm risk in the treatment group.

We also examine whether our results are due to general time-trends rather than the disruption of investment banking relationships. When we perform our difference-in-differences analysis around events that are shifted one year into the future or one year into the past, the 
difference-in-differences coefficients in our regressions are estimated with reduced economic and statistical significance.

Taken together, our results suggest that disruptions to investment banking relationships significantly affect corporate financing activity and extend our understanding of the real (capital spending) effects of financial shocks.

The objective of the paper is to contribute to the nascent literature investigating investment banking-client relationships in the wake of the financial crisis of 2007-2009. Fernando, May and Megginson (2012) and Kovner (2012) document in event studies that clients of the affected investment banks experience larger declines in their stock prices compared to clients of other investment banks upon the announcement of their investment bank's failure. While these papers investigate the value-relevance of underwriter relationships, our focus is on the potential for real effects of these relationships, and we investigate firms' actual financial and capital spending activities.

Moreover, we believe our analysis contributes to the literature on the real effects of financial shocks. As a result of the severe stress experienced on global financial markets during the financial crisis of 2007-2009, there has been increased interest in the effects of financial shocks on the real economy (a paper by Bond, Edmans and Goldstein, 2012, provides a survey). While existing literature has investigated shocks such as the loss of a security analyst (Derrien and Kecskés, 2013) or a relationship lender (Chodorow-Reich, 2014), the introduction of credit ratings on syndicated loans (Sufi, 2009), the refinement of credit ratings on corporate bonds (Tang, 2009), and the effect of stock prices on acquisition expenditures (Edmans, Goldstein and Jiang, 2012) and equity issuance (Khan, Kogan and Serafeim, 2012), we focus on the potential real effects brought about by the disruption of existing investment banking relationships. 
Our analysis contributes as well to the strand of literature that concentrates on the formation and characteristics of investment banking relationships. Asker and Ljungqvist (2010) document that firms' reluctance to share an underwriter with a product-market rival can have detrimental effects on the firms' investment spending. Ljungqvist, Marston and Wilhelm (2006, 2009) find that co-management opportunities are positively related to corresponding analyst optimism, and that this increases the probability of a future lead-management position. This literature primarily examines the development of investment banking relationships. We add the consequences of a major distortion of an already established relationship.

Additionally, we augment the understanding of the real value of investment banking relationships from a regulatory perspective. For example, Diamond and Rajan (2002) analyze ex post crisis costs of bank bailouts in terms of a possible change in aggregate liquidity. Especially with regard to Lehman Brothers, we extend this literature by concentrating on the reverse. If a distortion of the relationships between investment banks and clients induces severe negative consequences for the real economy, a regulator would do well to consider possible responses to such an event and take these costs into account.

Finally, we contribute to the overall real output and financing literature. Starting with the work by Fazzari, Hubbard, and Petersen (1988), an ever-growing body of the academic literature (see for example Barro 1990; Morck, Shleifer, and Vishny 1990; Blanchard, Rhee, and Summers 1993; or Lewellen and Lewellen 2014 for a more recent example and Stein (2003) for an overview of how market imperfections affect investment) has investigated the investment and financing decisions (and their interplay) of companies. Our paper contributes to the existing evidence by demonstrating that real output and investment decisions are affected by a distortion of the relationship with an important source of financing for companies. 
The paper proceeds as follows. Section 2 contains a description of the data and the statistical sample employed. Section 3 presents the empirical methodology. Section 4 reports the main results, and Section 5 reports additional analyses and robustness tests. Section 6 concludes.

\section{Data and Sample}

Consistent with the importance of an underwriter for firms (e.g. Asker and Ljungqvist, 2010), we use firms' equity and debt issuances to identify an investment banking relationship. We use the Securities Data Corporation (SDC) New Issues Database to identify all capital issues in the U.S. market in the ten-year period from 16 September 1998 to 16 September 2008. We follow earlier work such as Hansen (2001), Fernando, May and Megginson (2005) and Asker and Ljungqvist (2010) and exclude all issues by utilities, financials, and government entities (SIC Codes starting with 49, 6, and 9) from our sample. In order to classify capital-issuing firms by their respective investment bank, we also exclude all issues for which the corresponding underwriter or book-runner are not disclosed. We use Compustat for financial and accounting data and CRSP for stock return data. As we will explain in more detail below when outlaying our research design and methodology, our sample includes one year before the failure of Lehman Brothers, Bear Sterns, and Merrill Lynch (in most cases 2007) and one year after the failure of the three investment banks (in most cases 2009).

In examining the real effects of a shock to a company's investment banking relationship, we apply our analyses to four sets of corporate financial variables (following existing literature such as Derrien and Kecskés, 2013): investment spending, financing, dividends and cash holdings. Investment spending consists of capital expenditures (Compustat item capx, representing funds used for increases in property, plant, and equipment without additions from acquisitions), research and development costs (Compustat item xrd), and acquisition costs 
(Compustat item aqc). ${ }^{2}$ Financing comprises gross debt (Compustat item dltis) and equity issuance (Compustat item sstk) to reflect a firm's ability to source new funds in the capital market. We also introduce a net financial cash flow variable that includes debt reductions, stock repurchases and dividend payments to account for the net financial resources available to a firm from all sources (Compustat item fincf). Dividends are defined as cash payouts to shareholders (Compustat item dv), and cash holdings are defined as cash and short-term investments (Compustat item che). In our multivariate we use the following control variables: Size is the natural logarithm of a firm's total assets (Compustat item at), Age is the years since a company first appeared in Compustat, Cash Flow is operating income before depreciation (Compustat item oibdp), and Tobin's Q is calculated by dividing firm's market value (Compustat item prcc_f multiplied by Compustat item csho) plus a firm's total assets minus deferred taxes (Compustat item txdb) minus common equity (Compustat item ceq) by a firm's total assets. Except for firm size, age, and Tobin's Q, we scale our variables by lagged total assets (Compustat item at). To mitigate the influence of outliers, we winsorize our variables at the $1^{\text {st }}$ and $99^{\text {th }}$ percentiles.

Table 2 provides the descriptive statistics for the main variables used in the paper. The distribution of our financing variables is similar to that of papers using similar dependent variables, such as Derrien and Kecskés (2013).

\footnotetext{
2 There are alternative ways to measure corporate investment (and its components). There are different ways to scale the investment variables (e.g. Aggarwal and Samwick, 2006, Anderson and Garcia-Feijoo, 2006; Titman, Wei, and Xie, 2004, Smith and Watts, 1992; Vogt, 1997), and there are other measures to gauge a company's resources used for investing purposes (see Lewellen and Lewellen, 2014, for a discussion and overview). We experimented with these alternative definitions and variable constructions and found our results and inferences not to be significantly impacted by changes to variable definitions and computations.
} 


\section{Methodology}

We employ a difference-in-differences approach to analyze the real effects of the failure or virtual failure of the three aforementioned major investment banks on their clients. The treatment effect we are interested in estimating is the impact on investment spending and corporate financing brought about by a distortion of the investment banking relationship. To estimate this effect, we compare the group of companies impacted by that distortion to a control sample of unaffected companies. For the identification of the treatment group, we follow Kovner (2012) by restricting the period during which a company can be classified as being affiliated with a troubled underwriter.

Specifically, every company that used a troubled investment bank as lead underwriter for its last capital issue in the period between 16 September 2005 and 16 September 2008 (the three years before the failure of the three underwriters) is assigned to the treatment group. The remaining companies with available necessary data are assigned to the control group. This approach is also applied by James (1992) who shows that positive effects of a strong underwriter relationship decrease with a growing interval between two sequential issues. We relax this time constraint in additional tests in order to analyze the strength of the relationship. We then differentiate the treatment group by the strength of the underwriter relationship by also including issues where the investment bank did not hold a lead position in the underwriter syndicate. Overall, we expect the effects on our dependent corporate financial variables to increase with the intensity of this relationship.

Next, we define a pre- and post-treatment year for every sample firm. The treatment date of a firm is determined by the loss of its affiliated investment bank. If a firm is associated with several troubled investment banks, we adopt the conservative option and set the treatment date to 
the first point in time at which the relationship between client and underwriter becomes distorted. ${ }^{3}$ For the distortion to take effect, we introduce a transition period. The pre-treatment year is the first completed fiscal year ending three months before the treatment date, while the post-treatment year is the first completed fiscal year that began three months after the treatment date. The pre-treatment year of a Lehman Brothers client with a fiscal year-end of December $31^{\text {st }}$ would thus be fiscal year 2007 and the post-treatment year would be 2009 . There is no treatment date for our control group. However, since most of our sample firms have their fiscal year-end on December $31^{\text {st }}$, we define 2007 and 2009 as respective pre- and post-treatment years for our control group. Our difference-in-differences approach takes the form of the following regression equation:

$$
C F_{i}=\alpha+\beta_{1} \text { treated }_{i}+\beta_{2} \text { post }_{i}+\beta_{3} \text { treated }_{i} \times \text { post }_{i}+\bar{\gamma} \bar{C}+\varepsilon_{i}
$$

where $C F_{i}$ is the corporate financing variable of firm $i$, treated is a dummy variable that is equal to 1 if the firm is affiliated with a troubled investment bank and 0 otherwise. post is a dummy variable that is equal to 1 if the firm-year is the post-treatment year and 0 otherwise. The coefficient on the interaction variable treated $\times$ post is the difference-in-differences estimator. We are particularly interested in this coefficient because it suggests whether the pre- versus postdifference in $C P_{i}$ of treated companies is different from the pre- versus post-difference in $C P_{i}$ of control companies. If this term is negative, treated firms experience a stronger decrease in $C P_{i}$ than control firms. We cluster standard errors at the firm level. $\bar{\gamma}$ is a vector of regression

\footnotetext{
${ }^{3}$ Hence, if a company was a client of Lehman Brothers and Bear Stearns, the collapse of Bear Stearns is the earlier of both treatment dates. In this specific example, we would use March 2008 as treatment date for this firm. Since underwriting activity could still be shifted to Lehman Brothers after March 2008, this is a rather conservative approach.
} 
coefficients for the vector of control variables $\bar{C}$ that account for the variation in $C P$ that can be attributed to factors unrelated to investment banking relationships such as firm size (proxied by the natural log of firm's total assets), firm age (proxied by the number of years since a company first appeared in Compustat), cash flow and Tobin's Q (Fazzari, Hubbard and Petersen, 2000; Moyen, 2005). Finally, to mitigate concerns that our results reflect industry-specific factors unrelated to a distortion of underwriter relationships, we include industry-fixed effects.

In additional tests, we exclude the interaction variable treated $\times$ post and repeat the regression for treated and control firms in separate regressions. This allows for the inclusion of firm-fixed effects to control for unobservable firm-specific characteristics.

\section{Results}

\subsection{Do distortions of client-underwriter-relationships have real effects?}

Using our empirical setup, we examine the real and financial effects of a shock to a company's relationship with its lead underwriter. Table 3 presents the results of our main analysis, in which we estimate our difference-in-differences model and use the corporate finance dependent variables described in Section 2 and presented in Table 2. The focus is on the coefficient on treated $x$ post, our difference-in-differences estimator, which indicates the extent to which treated firms (i.e. firms experiencing a distortion of their investment banking relationship) differ in their corporate financing and real investment changes from pre-crisis to post-crisis compared to control firms (i.e. firms experiencing no shock to their underwriter relationship).

The first four columns report the results for Capex, $R \& D$ Expenses, Acquisition Expenses, and the sum of these variables, Total Investment. The results suggest that a distortion to a company's investment banking relationship does indeed have a considerable impact on its 
investment spending. Specifically, the first four columns show that treated firms cut their capital expenditures and acquisition outlays significantly more compared to the control firms. While the coefficient on post indicates that all sample firms reduce their investment spending, the total investment outlays of treated firms are reduced by roughly $6.3 \%$ more than the total investment outlays of control firms, a reduction that is significant at the 5\% level. This sizeable effect suggests that shocks to investment banking relationships have real effects for companies.

Bao and Edmans (2011) find support for the hypothesis that investment banks identify synergistic targets for their clients and negotiate favorable terms. Such beneficial aspects of M\&A advisory functions are even more pronounced for top-tier investment banks (Golubov, Petmezas and Travlos, 2012). To this end, a shock to an investment banking relationship may have a particularly negative effect on the acquisition outlays of a client. This linkage is also supported by the evident cross-selling efforts of investment banks (e.g. Drucker and Puri, 2005) as well as the strong reputation of the three aforementioned investment banks. Consistent with this notion, we find that the acquisition expenses of treated firms collapse more strongly than the other components of total investment (capital expenditures and research and development expenses) and decrease by $4.7 \%$ more than that of control firms. Since we identify investment banking relationships through clients' underwriting activities, this result suggests that underwriting relationships can extend to other investment banking services as well.

The next three columns report the results for Debt Issuance (gross), Equity Issuance, and Total Financing. Similar to the results for corporate investment outlays above, the significant difference-in-differences coefficients suggest that a distortion of a company's investment banking relationship has substantial impact on its access to financing. Specifically, treated firms reduce both their debt and equity issuance significantly more compared to control firms. 
Consequently, the total net financing of treated firms declines by about $12.4 \%$ more than the total net financing of control firms, a reduction that is significant at the $1 \%$ level. This indicates that shocks to investment banking relationships have a significant impact on companies' financing activities, in addition to their investment outlays, and suggests that companies experiencing a distortion of their investment banking relationship throughout the crisis subsequently face temporary financing difficulties in the capital markets.

Finally, we investigate corporate payouts and cash holdings in the last two columns of Table 3. We find no significant difference-in-differences effects with respect to dividend payments. For cash holdings, the difference-in-differences coefficient indicates that treated firms reduce their cash holdings by $3.7 \%$ more than control firms. These results suggest that treated firms reduce their cash holdings, possibly in an attempt to adjust to a limitation on outside funding (which presumably became harder to obtain due to the shock to the investment banking relationship) by accessing internal sources of capital. Alternatively (or additionally), treated firms may have reduced their cash holdings in order to be able to maintain previously established levels of dividend payouts.

Overall, the results of the estimation of our difference-in-differences research design presented in Table 3 are consistent with an interpretation that shocks to an investment banking relationship have a significant effect on companies' corporate behavior and are associated with a substantially negative impact on corporate investment and financing. ${ }^{4}$

\footnotetext{
4 To test whether the effects we document are temporary, in additional analyses, we run our difference-indifferences setting for post-crash years after 2009. We obtain two findings from these tests. First, the results do not immediately revert back to pre-crisis levels after the crisis, suggesting that alternative financing arrangements or the revival of Merrill Lynch, Bear Sterns and Lehman Brothers under new ownership did not ameliorate the problem on its own. Second, the further we move into the future beyond 2009, the weaker turn our results. We caution, however, that we are hesitant to infer too much from these findings as the risk of other potentially confounding events increases with every year after the investment bank failure of 2008.
} 


\subsection{Impact of the nature of the investment banking relationship}

Investment banking relationships ought to be more valuable in markets that are susceptible to high levels of asymmetric information (e.g., Myers and Majluf, 1984), such as the equity capital market. Consistently, Fernando, May and Megginson (2012) find the negative impact of the distortion of an investment banking relationship on client firms' market capitalization to be more pronounced for relationships that emerge from equity underwritings than debt underwritings. Consequently, we expect the effects on corporate investment and financing to be more pronounced for investment banking relationships that emerge from an equity underwriting. To test whether such heterogeneous treatment effects can also be observed in our sample under stress conditions, we split our treatment sample into firms that established their relationship on the basis of equity underwriting versus firms that base their relationship on debt underwriting. Table 4 presents the results of our previous analyses for treatment samples that are re-defined according to the nature of the investment banking relationship.

Firms with a former equity underwriting relationship with a failed investment bank do not show significant changes in debt financing, while their equity issuance activity significantly declines (13.1\%) compared to control firms. In contrast, treated firms with a prior debt underwriting relationship with a failed investment bank exhibit no significant effect on equity issuance, but they do issue significantly less debt (13.5\%) in comparison to the control group. Both of these differences are significant at the $1 \%$ level. The change in total net financing for equity underwritings is $14.6 \%$ lower than for control firms, while it is only $9.7 \%$ lower for debt underwritings (the difference is not statistically significant with a p-value of 0.17 ).

Interestingly, these differences are also reflected in the corporate capital spending variables. While firms that experience a shock to an equity underwriter relationship exhibit a 
decrease in capital expenditures that is $2.9 \%$ larger compared to control firms, this change is insignificant for firms with a shock to their debt underwriting relationship (the difference is statistically significant at the $1 \%$ level). On the other hand, the relative decrease of acquisition expenditures is economically and statistically significant for firms that established a debt underwriter relationship (7.3\%) whereas it is insignificant for firms that established an equity underwriter relationship (the difference is statistically significant at the 5\% level). This is not only consistent with the fact that acquisitions are predominantly financed by debt rather than equity but also with the notion that investment banking relationships may be used to cross-sell acquisition advisory services. ${ }^{5}$

Finally, the comparatively more pronounced effects of the distortion of an equity underwriting relationship are also reflected to some degree in corporate cash holdings. The reduction in cash holdings is significant for firms with a distortion of an equity underwriting relationship (5.8\%) and insignificant for firms that experienced a distortion of their debt underwriting relationship (3.4\%) (the difference is not statistically significant with a p-value of 0.16 ).

Overall, the results presented in Table 4 lend support to the negative impact of a distortion of an investment banking relationship on corporate financing and investment spending. They also contribute to our understanding of the differential importance and impact of debt and equity underwriting relationships.

\footnotetext{
${ }^{5}$ We note that an even finer classification of debt-based investment banking relationship is possible. Specifically, one can distinguish between net new bond issues and bond refundings during the period prior to the crash. Net new bond issues have fundamentally different capital-raising implications compared to refundings. When we split our group of debt-based investment relationship firms by firm age (mature firms with more cash holdings are presumably more likely to refinance as interest rates fell during the 1996 to 2008 period before the crash), we do indeed find that the negative consequences on investment of a distorted investment banking relationship is only present for young firms (who presumably have issued new bonds to finance expansion projects).
} 


\subsection{Impact of the strength of the investment banking relationship}

If it is indeed the investment banking-relationship effect that drives the results presented so far, we should reasonably expect these results to become less pronounced with a decrease in the strength of the investment banking relationship.

In a first test, we proxy such a decrease by the role the investment bank plays in the client's underwriting syndicate. Specifically, we assign a company to the treatment group if a troubled investment bank was part of the underwriting syndicate but not mandated as the lead underwriter (we exclude observations where a troubled investment bank was lead underwriter in these estimations). In unreported results, we note that the coefficients on the interaction variables generally decrease substantially in economic magnitude and statistical power. The coefficients on Total Investment, Total Financing, as well as Cash Position become insignificant. The coefficient on Equity Issuance is reduced from $7.4 \%$ to $3.1 \%$ (significant only at the $10 \%$ level of significance).

In a next step, we model the strength of an investment banking relationship by the time that has passed since the last occurrence of a troubled investment bank acting as lead underwriter. In previous tests, we constrained the time period in which a firm can become affiliated with an investment bank to the three years preceding September 2008. Relaxing this constraint, we expect the effect of a shock to an investment banking relationship to decrease over time. If investment banks can exploit economies of scale by recycling proprietary information of clients (James, 1992), these benefits should disappear over time as the information become obsolete.

We gradually extend the affiliation period used to classify companies as treated by intervals of one year. In the most extreme case, we take into account all deals that fall into the 
10-year period leading up to September 2008. Table 5 presents the results of the estimation of our difference-in-differences model with these alternative treatment groups. For reasons of space we report only the difference-in-differences coefficient for each regression.

Overall, we observe a virtually monotonic decrease in the magnitude and significance of the differences between the treatment and control groups in the number of years added to the affiliation period for our corporate investment expenditure variables. With respect to the corporate financing variables, the reduction in significance is somewhat less pronounced, but the economic magnitude is substantially reduced. Companies for which more time elapsed since the last contact to their relationship investment bank seem to be less economically affected by the shock to the investment banking relationship. For example, the reduction in total investment spending of treated firms is $6.3 \%$ larger than for control firms for an affiliation period of three years. This number decreases to an insignificant $1.6 \%$ if we expand the affiliation period to 5 years. At the same time, the reduction of total debt and equity financing of treated firms is $12.4 \%$ larger than for control firms for an affiliation period of three years. This decreases to $2.0 \%$ and becomes insignificant when we expand the affiliation period to 10 years.

These results lend support to the notion that our main findings can be attributed to a relationship-specific channel and are indeed related to the distortion to the relationship between a lead underwriter and its client firm.

\section{Additional analyses and robustness checks}

\subsection{Alternative explanation: Differences between treated and control groups}

In the main analyses of our paper, our sample consists of a treatment sample (companies that had established a relationship with a troubled underwriter pre-crisis) and a control sample (companies with available data but without a relationship to a troubled underwriter pre-crisis). 
But companies that frequently employ an investment bank for external financing arrangements differ from the overall pool of firms. In particular, it could be that firms using investment banks are younger, smaller, and/or more rapidly growing than the average firm in Compustat. Descriptive statistics comparing treated and control firms in the year prior to the disruption of underwriting relationships provided in the first three columns of Panel A of Table 6 partly confirm this hypothesis.

In the context of our paper, this could leave room for an alternative explanation of our results, where it is not the relationship with a troubled investment bank but differing degrees in dependence on external funding that explains our results. To investigate the possibility that differences between treated and control firms unduly affect our inferences, we apply a matching procedure that aims at constructing a control sample that is comparable to our treatment sample.

We proceed as follows: For every treated firm in the year prior to the onset of the financial crisis we look for a control firm that is in the same two-digit-SIC industry and then select the control firm closest to the treated firm in the prior year along a number of matching dimensions. In addition to industry, our matching procedure uses size, sales growth, profitability (proxied for by return on assets), investment opportunities (proxied for by Tobin's Q), and firm age. We measure the closeness between two firms by calculating the Mahalanobis distance, which measures the distance between characteristics of firms and also takes into account the covariances between the characteristics and the variances of the characteristics themselves (see Chernenko and Sunderam, 2012, for an example of this approach in another context).

The two columns in the right of Table 6 Panel A show that our matching procedure is successful at matching treated firms with control firms that are very similar along the observable dimensions used in the matching algorithm. Panel A of Table 6 shows that after the matching 
procedure described above, there are no significant differences remaining among treated and control groups along the matching dimensions.

In a next step, we re-run our baseline difference-in-difference regression using a sample that consists of the treatment sample and the matched control sample. If differences between treatment and control groups influence our results, we would expect the interaction terms between the treated and the post-year dummy to turn insignificant in these specifications. The results reported in Panel B of Table 6 (focusing on the difference-in-differences coefficients) show that this is not the case. The results are similar to the coefficients in Table 3 and document a statistically and economically significantly higher degree in reduction of key corporate investing and financing policies for our treatment companies compared to a matched sample of control firms (the only difference is the effect on cash holdings, which is not significant anymore).

These results indicate that our main results as shown in Table 3 are not driven by heterogeneity in the cross-section between treatment and control samples. In particular, our results demonstrate that differences in size, sales growth rate, profitability, investment opportunities, or firm age do not drive our results.

\subsection{Alternative explanation: Unobservable firm characteristics that are unrelated to underwriter relationships}

One could argue that the effects documented above are not related to firms' relationships to their investment banks, but rather to other investment bank-specific factors, such as the loss of a lending relationship. We provide two pieces of evidence that appear to refute such an alternative explanation. 
First, we presuppose that Bear Stearns, Lehman Brothers and Merrill Lynch cross-sell wholesale financial services (e.g., revolving credit lines, bridge- and staple-financing, etc.) to their investment banking clients (Drucker and Puri, 2005). If our results are unrelated to the distortion of an underwriter relationship, but instead driven by wholesale banking services no longer available from the relationship investment bank, the impact should become substantially weaker when we exclude control firms that do not have material contractual exposure to any of the three troubled investment banks. That is, both treated and control firms may have material wholesale banking exposure to one of the three troubled investment banks, and we proceed to measure the incremental effect of an underwriting relationship. To this end, we screen every 8-K, 10-Q, and 10-K filings (obtained from the SEC Edgar database) by sample companies between July 2008 and December 2009. We screen these documents for links to Bear Stearns, Lehman Brothers, or Merrill Lynch, isolating control firms that are dropped from the sample. Repeating our analyses on the basis of this constrained sample leaves our results basically unchanged. Treated firms still exhibit significantly sharper decreases in corporate investment, financing and cash holdings over the control group.

Second, we employ a firm-fixed effects model to account for unobservable firm-specific characteristics that may not have been picked up in our screening of SEC filings. The results are summarized in Table 7. Regressing treated and untreated firms separately and including firmfixed effects in these regressions, ${ }^{6}$ we find that the change in capital outlays, acquisition expenditures, total investment, debt issuance, equity issuance, total financing, as well as the amount of cash holdings from pre-crisis to post-crisis levels is significantly more negative for treated firms than for control firms. All of these variables are significant at least at the $5 \%$ level.

\footnotetext{
${ }^{6}$ Note that it is not possible to include firm-fixed effects in full sample estimations of our difference-in-differences model, because the firm-fixed effects for a company are collinear with the treatment dummy.
} 
To validate the difference in the coefficients from the two separate regressions, we conduct a Chow (1960) test. The coefficients are different from each other at the 5\% significance level or better (with the exception of capital outlays, where the difference is significant at the $10 \%$ level). The high levels of $\mathrm{R}^{2}$ show that the fixed effects pick up substantial amounts of variance in the dependent variables that our control variables are not able to explain. The consistency of these results with our full-sample evidence corroborates our interpretation that the effects on corporate investment and financing are due to a relationship-specific channel.

\subsection{Robustness: Lehman Brothers vs. Other Troubled Underwriters}

Under the premise that the severity of the investment banking relationship shock is directly related to the nature of the financial crisis, we hypothesize that our documented treatment effect is different for the clients of Lehman Brothers - the only one of the three troubled investment banks that actually filed for bankruptcy. To investigate this hypothesis, we differentiate treated firms according to the nature of their underwriter's collapse and divide our treatment group into two subsamples. We then repeat our analysis. The first subsample contains only clients that were affiliated with Lehman Brothers, the second subsample contains only clients affiliated with Bear Stearns and Merrill Lynch. We present the results of this analysis (focusing on the difference-in-differences coefficients) in Table 8. The results suggest that our main findings presented in Table 3 are not exclusively driven by the subsample Lehman Brothers clients, but there are differences between the two groups. Clients of Lehman Brothers (Panel A) experience a significant drop in capital expenditures (the reduction for clients of the other two investment banks (Panel B) is not significant) and the coefficients (and their statistical significance) are generally higher for Lehman Brothers clients. We caution, however, that the differences are not statistically significant. 


\subsection{Alternative Explanation: Major Investment Banks}

The three investment banks determining the treatment group belonged to the largest players in the investment banking industry prior to the financial crisis. The control group, however, also comprises a number of considerably smaller underwriters with potentially different reputation (Fernando, Gatchev, May and Megginson, 2013). On the one hand, the effect of the investment bank relationship might be correlated with the size of the firm. On the other hand, based on their league table standing, the three distressed investment banks may attract a more homogenous client group. Against the backdrop of a positive assortative-matching process between underwriter and client (Fernando, Gatchev and Spindt, 2005), a straightforward way of increasing the homogeneity in the control group is an increase in the homogeneity of their underwriters.

We therefore constrain the control sample to clients of the top 25 underwriters based on 2007 league tables for equity and debt underwritings. In unreported results, we find that treated companies still show a significant decrease in total investment spending, total financing and cash holdings as compared to the control sample. Despite a decrease in sample size, the results remain virtually unchanged in both magnitude and levels of significance.

\subsection{Alternative Explanation: Firm Risk}

As a further robustness test, we analyze whether treatment and control groups differ with respect to risk. It is possible that the three distressed investment banks were attracting systematically more risky clients. Consequently, a comparatively larger decline in treated firms' corporate financial and performance variables might not be related to the distortion of an underwriter relationship, but rather to a relatively more pronounced reaction to the financial 
crisis. Since our sample is constrained to U.S. companies and the average firm size is quite large, we proxy the systematic risk of a firm by its beta with respect to the S\&P 500 index.

Excluding firms with less than 100 return observations, we calculate five beta values, based on the daily returns between one and five years before 2008. Comparing the average beta of treated and untreated firms for the five sample periods, we find that treated firms do not exhibit significantly higher beta coefficients for any of the calculation periods in our study. ${ }^{7}$

\subsection{Alternative Explanation: Time Trends}

It is possible that our results do not stem from a distortion of the treated firms' relationship to their respective investment banks, but rather from alternative factors specific to our treatment group or the regression design. Accordingly, we conduct a placebo test and run our analyses under conditions wherein the shock to the investment banking relationship occurred either one year before or one year after the actual shock. ${ }^{8}$ If a time trend among treated firms leads to the investment expenditure and financing effects that we have documented, we would expect our results to remain unchanged by the shift of the event-timing. If, on the other hand, the effects are the result of a disruption to treated firms' investment banking relationships, we would expect the counterfactual difference-in-differences coefficients to have reduced economic and statistical significance in the placebo tests. In unreported results, we indeed find this to be the case.

In a further test, we hold the pre- and post-treatment years constant while randomly assigning firms to the treatment and control group. Once again the results become statistically insignificant, suggesting that our findings are specific to our treatment corporations and not

\footnotetext{
${ }^{7}$ Our results are robust to using different proxies for risk such as leverage, return volatility, and volatility of Earnings before Interest and Taxes (EBIT).

${ }^{8}$ Although we maintain all criteria for the selection of our treatment and control group, we note that small differences in the sample composition can arise due to data availability.
} 
associated with a general crisis or time-trend effect. Overall, these additional tests shed further light on a potentially causal interpretation of our results. The findings appear to be unrelated to the time-frame around 2008 or to a general time trend among treated firms.

\section{Conclusions}

In this paper, we focus on the failure of three major investment banks during the financial crisis of 2007-2009 as an empirical setting to investigate the real effects of a distortion in investment banking relationships. Employing a difference-in-differences approach, our results suggest that clients of a troubled investment bank reduce their investment expenditures and financing activities significantly more than a sample of control firms whose relationships with their underwriters were unaffected. A series of robustness checks and further analyses provides evidence inconsistent with alternative explanations. We suggest that evidence gleaned from the financial turbulence of 2007-09 contributes to the literature examining the relevance of underwriter relationships and the literature documenting the real economic impact of shocks in financial markets. 


\section{References}

Aggarwal, R. and A. Samwick (2006): Empire-builders and shirkers: Investment, firm performance, and managerial incentives, Journal of Corporate Finance 3, 489-515.

Anderson, C. and L. Garcia-Feijoo (2006): Empirical evidence on capital investment, growth options, and security returns, Journal of Finance 61, 171-194.

Asker, J. and A. Ljungqvist (2010): Competition and the structure of vertical relationships in capital markets, Journal of Political Economy 118, 599 - 647.

Bao, J. and A. Edmans (2011): Do investment banks matter for M\&A returns? Review of Financial Studies 24, $2286-2315$.

Barro, R. (1990): The stock market and investment, Review of Financial Studies 3, 115-131.

Blanchard, O., C. Rhee and L. Summers (1993): The stock market, profit, and investment, Quarterly Journal of Economics 108, 115-136.

Bond, P., A. Edmans, and I. Goldstein (2012): The real effects of financial markets, Annual Reviews of Financial Economics 4, 339 - 360.

Burch, T. R., V. Nanda, and V. Warther (2005): Does it pay to be loyal? An empirical analysis of underwriting relationships and fees, Journal of Financial Economics 77, $673-699$.

Chernenko. S. and A. Sunderam (2012): The Real Consequences of Market Segmentation, Review of Financial Studies 25, $2041-2069$.

Chodorow-Reich, G. (2014): The employment effects of credit market disruptions: Firm-level evidence from the 2008-2009 Financial Crisis, Quarterly Journal of Economics 129, 1 - 52.

Chow, G. C. (1960): Tests of Equality Between Sets of Coefficients in Two Linear Regressions, Econometrica 28, $591-605$.

Derrien, F. and A. Kecskés (2013): The Real Effects of Financial Shocks: Evidence from Exogenous Changes in Analyst Coverage, Journal of Finance 68, 1407 - 1440.

Diamond, D. W. and R. G. Rajan (2002): Bank Bailouts and Aggregate Liquidity, American Economic Review 92, 38 - 41.

Drucker, S. and M. Puri (2005): On the benefits of concurrent lending and underwriting, Journal of Finance 60, 2762 - 2799.

Edmans, A., I. Goldstein, and W. Jiang (2012): The real effects of financial markets: The impact of prices on takeovers, Journal of Finance 67, 933 - 971. 
Fazzari, S. M., R. G. Hubbard, and B. C. Petersen (2000): Investment-cash flow sensitivities are useful: A comment on Kaplan and Zingales, Quarterly Journal of Economics 115, 695 - 705.

Fernando, C. S., V. A. Gatchev, and P. A. Spindt (2005): Wanna dance? How firms and underwriters choose each other, Journal of Finance 60, 2437 - 2469.

Fernando, C. S., A. D. May, and W. L. Megginson (2012): The value of investment banking relationships: Evidence from the collapse of Lehman Brothers, Journal of Finance 67, 235 - 270.

Fernando, C. S., V. A. Gatchev, A. D. May, and W. L. Megginson (2013), Prestige without purpose? What a top underwriter's reputation is really worth, Working Paper, University of Oklahoma.

Gao, X. and J. R. Ritter (2010): The marketing of seasoned equity offerings, Journal of Financial Economics 97, $32-52$.

Gobulov A., D. Petmezas, and N. G. Travlos (2012): When it pays to pay your investment banker: New evidence on the role of financial advisors in M\&As, Journal of Finance 67, 271 311.

Hansen, R. S. (2001): Do investment banks compete in IPOs? The advent of the $7 \%$ plus contract, Journal of Financial Economics 59, 313 - 346.

Hansen, R. S. and P. Torregrosa (1992): Underwriter compensation and corporate monitoring, Journal of Finance 47, 1537 - 1555.

James, C. (1992): Relationship-specific assets and the pricing of underwriter services, Journal of Finance 47, $1865-1885$.

Khan, M., L. Kogan, and G. Serafeim (2012): Mutual fund trading pressure: Firm-level stock price impact and timing of SEOs, Journal of Finance 67, 1371 - 1395.

Kovner, A. (2012): Do underwriters matter? The impact of the near loss of an equity underwriter, Journal of Financial Intermediation 21, 507 - 529.

Lewellen, J. and K. Lewellen (2014): Investment and cashflow: New evidence, Journal of Financial and Quantitative Analysis, forthcoming.

Ljungqvist, A., Marston F., and W. J. Wilhelm (2006): Competing for securities underwriting mandates: Banking relationships and analyst recommendations, Journal of Finance 61, 301 340 .

Ljungqvist, A., Marston F., and W. J. Wilhelm (2009): Scaling the hierarchy: How and why investment banks compete for syndicate co-management appointments, Review of Financial Studies 22, $3977-4007$. 
Megginson, W. L. and K. A. Weiss (1991): Venture capitalist certification in initial public offerings, Journal of Finance 46, 879 - 903.

Moyen, N. (2005): Investment-cash flow sensitivities: Constrained versus unconstrained firms, Journal of Finance 59, 2061 - 2092.

Myers, S. C. and N. S. Majluf (1984): Corporate financing and investment decisions when firms have information that investors do not have, Journal of Financial Economics 13, $187-221$.

Smith, C. and R. Watts (1992): The Investment Opportunity Set and Corporate Financing, Dividend, and Compensation Policies, Journal of Financial Economics 32, 263 - 292.

Stein, J. (2003): Agency, information and corporate investment, in: Constantinides, G., M. Harris, and R. Stulz (eds.), Handbook of the Economics of Finance. Amsterdam: Elsevier Science.

Sufi, A. (2009): The real effects of debt certification: Evidence from the introduction of bank loan ratings, Review of Financial Studies 22, 1659 - 1691.

Tang, T. T. (2009): Information asymmetry and firms' credit market access: Evidence from Moody's credit rating format refinement, Journal of Financial Economics 93, 325 - 351.

Titman, S., K.C.J. Wei and F. Xie (2004): Capital investments and stock returns, Journal of Financial and Quantitative Analysis 39, 677-700.

Vogt, S. (1997): Cash Flow and Capital Spending: Evidence from Capital Expenditure Announcement, Financial Management 26, 44 - 57. 
Table 1 Overview of underwriting market by type of issue and syndicate role

\begin{tabular}{|c|c|c|c|c|c|c|c|c|c|}
\hline \multirow{2}{*}{$\frac{\text { Panel A }}{\text { Type of issue }}$} & \multicolumn{2}{|c|}{ Troubled bookrunner } & \multicolumn{2}{|c|}{ Troubled underwriter } & \multirow{2}{*}{ Total } & \multirow{2}{*}{$\frac{\text { Panel B }}{\text { Type of issue }}$} & \multicolumn{3}{|c|}{ Allotment amounts by type of underwriter } \\
\hline & no & yes & no & yes & & & untroubled & troubled & Total \\
\hline \multirow[t]{2}{*}{ Common Stocks } & 5,024 & 1,563 & 3,457 & 3,130 & 6,587 & Common Stocks & 709,112 & 166,570 & 875,682 \\
\hline & $76.27 \%$ & $23.73 \%$ & $52.48 \%$ & $47.52 \%$ & & & $80.98 \%$ & $19.02 \%$ & \\
\hline \multirow[t]{2}{*}{ Convertible } & 936 & 413 & 713 & 636 & 1,349 & Convertible & 87,414 & 21,356 & 108,770 \\
\hline & $69.38 \%$ & $30.62 \%$ & $52.85 \%$ & $47.15 \%$ & & & $80.37 \%$ & $19.63 \%$ & \\
\hline \multirow[t]{2}{*}{ Equity registration pipeline } & 1,183 & 279 & 1,003 & 459 & 1,462 & Equity registration pipeline & 0 & 0 & 0 \\
\hline & $80.92 \%$ & $19.08 \%$ & $68.60 \%$ & $31.40 \%$ & & & & - & \\
\hline \multirow[t]{2}{*}{ Medium term note programs } & 242 & 54 & 108 & 188 & 296 & Medium term note programs & 0 & 0 & 0 \\
\hline & $81.76 \%$ & $18.24 \%$ & $36.49 \%$ & $63.51 \%$ & & & - & - & \\
\hline \multirow[t]{2}{*}{ Mortgage asset backed } & 1,216 & 612 & 855 & 973 & 1,828 & Mortgage asset backed & 10,083 & 1,111 & 11,194 \\
\hline & $66.52 \%$ & $33.48 \%$ & $46.77 \%$ & $53.23 \%$ & & & $90.07 \%$ & $9.93 \%$ & \\
\hline \multirow[t]{2}{*}{ Nonconvertible debt } & 9,636 & 3,147 & 7,807 & 4,976 & 12,783 & Nonconvertible debt & $2,193,476$ & 368,640 & $2,562,116$ \\
\hline & $75.38 \%$ & $24.62 \%$ & $61.07 \%$ & $38.93 \%$ & & & $85.61 \%$ & $14.39 \%$ & \\
\hline \multirow[t]{2}{*}{ Preferred stock } & & 102 & 59 & 130 & 189 & Preferred stock & 16,801 & 7,855 & 24,656 \\
\hline & $46.03 \%$ & $53.97 \%$ & $31.22 \%$ & $68.78 \%$ & & & $68.14 \%$ & $31.86 \%$ & \\
\hline \multirow[t]{2}{*}{ Private debt } & 2,371 & 234 & 2,352 & 253 & 2,605 & Private debt & 0 & 0 & 0 \\
\hline & $91.02 \%$ & $8.98 \%$ & $90.29 \%$ & $9.71 \%$ & & & - & - & \\
\hline \multirow[t]{2}{*}{ Private equity } & 1,750 & 211 & 1,748 & 213 & 1,961 & Private equity & 73 & 0 & 73 \\
\hline & $89.24 \%$ & $10.76 \%$ & $89.14 \%$ & $10.86 \%$ & & & $100.00 \%$ & $0.00 \%$ & \\
\hline \multirow[t]{2}{*}{ Registration debt } & 152 & & 124 & & 210 & Registration debt & 130 & 195 & 325 \\
\hline & $72.38 \%$ & $27.62 \%$ & $59.05 \%$ & $40.95 \%$ & & & $40.00 \%$ & $60.00 \%$ & \\
\hline \multirow[t]{2}{*}{ Total } & 22,597 & 6,673 & 18,226 & $\overline{11,044}$ & 29,270 & Total & $\overline{3,017,089}$ & $\overline{565,727}$ & $3,582,816$ \\
\hline & $77.20 \%$ & $22.80 \%$ & $62.27 \%$ & $37.73 \%$ & & & $84.21 \%$ & $15.79 \%$ & \\
\hline
\end{tabular}

Table 1 provides information on the market share of the following three underwriters: Bear Stearns, Lehman Brothers, and Merrill Lynch. The sample comprises all deals with an identifiable underwriter from the SDC Platinum New Issues database over the ten years preceding the collapse of Lehman Brothers on 09/16/08. Panel A refers to the participation of a troubled investment bank in underwriting syndicates as bookrunners or underwriters. Panel B refers to the specific deal amounts allotted to one of the three investment banks. 
Table 2 Descriptive statistics for corporate policy and control variables

\begin{tabular}{|c|c|c|c|c|c|c|}
\hline \multicolumn{7}{|c|}{ Panel A: Corporate policy variables } \\
\hline Variable Name & $\mathrm{n}$ & mean & sd & p25 & p50 & p75 \\
\hline Capex & 2,799 & 0.06 & 0.08 & 0.02 & 0.03 & 0.07 \\
\hline R\&D Expenses & 2,804 & 0.05 & 0.10 & 0.00 & 0.00 & 0.06 \\
\hline Acquisition Expenses & 2,683 & 0.04 & 0.12 & 0.00 & 0.00 & 0.02 \\
\hline Total Investment & 2,681 & 0.16 & 0.19 & 0.04 & 0.09 & 0.19 \\
\hline Debt Issuance (gross) & 2,692 & 0.14 & 0.30 & 0.00 & 0.01 & 0.14 \\
\hline Equity Issuance & 2,754 & 0.06 & 0.17 & 0.00 & 0.00 & 0.02 \\
\hline Total Financing & 2,801 & 0.04 & 0.25 & -0.06 & -0.01 & 0.03 \\
\hline Cash Dividends & 2,778 & 0.01 & 0.03 & 0.00 & 0.00 & 0.01 \\
\hline Cash Holdings & 2,804 & 0.22 & 0.26 & 0.04 & 0.12 & 0.30 \\
\hline \multicolumn{7}{|c|}{ Panel B: Control variables } \\
\hline Variable Name & $\mathrm{n}$ & mean & sd & p25 & p50 & p75 \\
\hline Size & 2,804 & 6.90 & 1.66 & 5.62 & 6.75 & 7.93 \\
\hline Age & 2,804 & 14.41 & 4.97 & 10.00 & 18.00 & 20.00 \\
\hline Cash flow & 2,804 & 0.10 & 0.16 & 0.05 & 0.12 & 0.18 \\
\hline Tobin's Q & 2,642 & 1.88 & 1.20 & 1.13 & 1.49 & 2.17 \\
\hline
\end{tabular}

Table 2 reports descriptive statistics for the corporate financial and control variables. Capex denotes capital expenditures (Compustat item capx), R\&D Expenses denotes research and development expenses (Compustat item xrd), Acquisition Expenses denotes acquisition expenses (Compustat item aqc), Total Investment denotes the sum of Capex, R\&D Expenses, and Acquisition Expenses. Debt Issuance (gross) denotes gross long-term debt issuance (Compustat item dltis), Equity Issuance denotes the sale of common and preferred stock (Compustat item sstk), Total Financing denotes the total net cash flow from financing activities (Compustat item fincf). Dividends denotes cash dividends (Compustat item dv). Cash Holdings denotes cash and short-term investments (Compustat item che). All dependent variables are scaled by lagged total assets (Compustat item at). Size denotes the natural of of total assets (Compustat item at). Age denotes firm age measured as the time since a firm first appeared in Compustat. Cash flow denotes operating income before depreciation (Compustat item oibdp) scaled by lagged total assets (Compustat item at). Tobin's Q denotes the ratio of a firm's market value (Compustat item prcc_f multiplied by Compustat item csho) plus a firm's total assets minus deferred taxes (Compustat item txdb) minus common equity (Compustat item ceq) divided by a firm's total assets. n denotes the number of firm-year observations. All variables are winsorized at the $1 \%$ and $99 \%$ level. 
Table 3 Results of basic regression model with troubled bookrunners as identification variable for our treatment sample

\begin{tabular}{|c|c|c|c|c|c|c|c|c|c|}
\hline $\begin{array}{l}\text { Dependent } \\
\text { Variable }\end{array}$ & Capex & $\begin{array}{c}R \& D \\
\text { Expenses }\end{array}$ & $\begin{array}{c}\text { Acquisition } \\
\text { Expenses }\end{array}$ & $\begin{array}{c}\text { Total } \\
\text { Investment }\end{array}$ & $\begin{array}{c}\text { Debt Issuance } \\
\quad \text { (gross) }\end{array}$ & $\begin{array}{l}\text { Equity } \\
\text { Issuance }\end{array}$ & $\begin{array}{c}\text { Total } \\
\text { Financing }\end{array}$ & $\begin{array}{c}\text { Cash } \\
\text { Dividends }\end{array}$ & $\begin{array}{c}\text { Cash } \\
\text { Position }\end{array}$ \\
\hline \multirow[t]{2}{*}{ Cash flow } & $0.071^{* * * *}$ & $-0.263^{* * * *}$ & $0.133^{\text {**** }}$ & $-0.074^{*}$ & $0.277^{* * * *}$ & $-0.276^{\text {**** }}$ & $-0.378^{* * * *}$ & $0.030^{* * * *}$ & $-0.350^{* * * * *}$ \\
\hline & $(5.367)$ & $(-13.115)$ & $(5.751)$ & $(-1.835)$ & $(4.612)$ & $(-6.702)$ & $(-6.495)$ & $(6.206)$ & $(-7.133)$ \\
\hline \multirow[t]{2}{*}{ Age } & $-0.002^{* * * *}$ & -0.000 & $-0.002^{* * * *}$ & $-0.005^{* * * *}$ & $-0.005^{* * *}$ & $-0.004^{* * * *}$ & $-0.008^{\text {**** }}$ & 0.000 * & $-0.004^{* * * *}$ \\
\hline & $(-4.472)$ & $(-1.095)$ & $(-2.642)$ & $(-4.922)$ & $(-3.211)$ & $(-5.132)$ & $(-6.254)$ & (1.764) & $(-2.947)$ \\
\hline \multirow[t]{2}{*}{ Size } & -0.001 & $-0.004^{* * *}$ & 0.003 & -0.002 & 0.006 & $-0.005^{* * *}$ & 0.001 & $0.002^{* * * *}$ & $-0.026^{* * * * *}$ \\
\hline & $(-0.885)$ & $(-3.774)$ & (1.563) & $(-0.797)$ & (1.199) & $(-2.746)$ & $(0.367)$ & (3.710) & $(-7.723)$ \\
\hline \multirow[t]{2}{*}{ Tobin's Q } & $0.008^{* * * *}$ & $0.028^{* * * *}$ & $-0.007^{* * * *}$ & $0.032^{\text {**** }}$ & $-0.016^{* * * *}$ & $0.042^{* * * *}$ & 0.026 **** & $0.004^{* * * *}$ & $0.082^{* * * * *}$ \\
\hline & $(4.221)$ & (13.016) & $(-3.279)$ & (8.098) & $(-2.890)$ & $(8.897)$ & $(4.254)$ & (4.994) & (13.259) \\
\hline \multirow[t]{2}{*}{ Treated } & $0.015^{*}$ & 0.001 & $0.051^{* * * *}$ & $0.066^{* * * *}$ & $0.108^{* * * *}$ & $0.073^{* * *}$ & $0.119^{\text {**** }}$ & 0.001 & 0.029 \\
\hline & (1.865) & $(0.212)$ & (2.932) & $(2.928)$ & (3.214) & (3.408) & (3.948) & $(0.424)$ & $(1.440)$ \\
\hline \multirow[t]{2}{*}{ Post } & $-0.027^{* * * *}$ & -0.003 & $-0.035^{\text {**** }}$ & $-0.070^{* * * *}$ & $-0.065^{* * *}$ & $-0.024^{* * * *}$ & -0.058 **** & -0.000 & 0.007 \\
\hline & $(-10.756)$ & $(-1.625)$ & $(-7.691)$ & $(-10.527)$ & $(-6.889)$ & $(-4.042)$ & $(-6.813)$ & $(-0.614)$ & (1.028) \\
\hline \multirow[t]{2}{*}{ Treated*Post } & $-0.015^{* * *}$ & 0.002 & -0.047 ***** & $-0.063^{* *}$ & $-0.095^{* * * *}$ & $-0.074^{* * * *}$ & $-0.124^{* * * *}$ & -0.001 & $-0.037^{* * *}$ \\
\hline & $(-2.065)$ & $(0.338)$ & $(-2.596)$ & $(-2.516)$ & $(-2.672)$ & $(-3.132)$ & $(-3.848)$ & $(-0.439)$ & $(-1.966)$ \\
\hline \multirow[t]{2}{*}{ Constant } & $0.088^{* * * *}$ & $0.062^{* * * *}$ & $0.061^{* * * *}$ & $0.223^{* * * *}$ & $0.208^{* * * *}$ & $0.117^{* * *}$ & $0.163^{* * * *}$ & $-0.016^{* * * *}$ & $0.332^{* * * *}$ \\
\hline & (10.108) & $(6.451)$ & $(4.385)$ & (10.922) & (5.614) & (6.369) & $(6.181)$ & $(-4.794)$ & (11.372) \\
\hline $\mathrm{N}$ & 2,588 & 2,593 & 2,481 & 2,479 & 2,492 & 2,548 & 2,590 & 2,568 & 2,593 \\
\hline $\mathrm{R}^{2}$ & 0.410 & 0.606 & 0.115 & 0.233 & 0.125 & 0.260 & 0.200 & 0.186 & 0.457 \\
\hline
\end{tabular}

Table 3 reports the results of the estimation of the difference-in-differences model. Capex denotes capital expenditures (Compustat item capx), $R \& D$ Expenses denotes research and development expenses (Compustat item xrd), Acquisition Expenses denotes acquisition expenses (Compustat item aqc), Total Investment denotes their sum. Debt Issuance (gross) denotes gross long-term debt issuance (Compustat item dltis), Equity Issuance denotes the sale of common and preferred stock (Compustat item sstk). Total Financing denotes the total net cash flow from financing activities (Compustat item fincf). Cash Dividends denotes cash dividends (Compustat item dv). Cash Holdings denotes cash and short-term investments (Compustat item che). All dependent variables are scaled by lagged total assets and winsorized at the $1 \%$ and $99 \%$ level.

Cash flow denotes operating income before depreciation (Compustat item oibdp) scaled by lagged total assets, Age denotes firm age, Size denotes total assets (Compustat item at). Treated is a dummy variable that is equal to 1 if a company has used a troubled investment bank as lead underwriter in the three years leading up to the financial crisis. Post is a dummy variable equal to 1 for post-crash firm-years. Treated $*$ Post denotes the difference-in-differences coefficient. All specifications include industry fixed effects. The values in parentheses represent t-values based on standard errors clustered at the firm level. *** indicates significance at the $1 \%$ level, $* *$ indicates significance at the $5 \%$ level, and $*$ indicates significance at the $10 \%$ level. 
Table 4 Results of basic regression model for an established debt or equity relationship

\begin{tabular}{|c|c|c|c|c|c|c|}
\hline \multirow{2}{*}{$\begin{array}{l}\text { Dependent } \\
\text { Variable }\end{array}$} & \multicolumn{3}{|c|}{ Debt Relationship } & \multicolumn{3}{|c|}{ Equity Relationship } \\
\hline & Treated*Post & $\mathrm{N}$ & $\mathrm{R}^{2}$ & Treated*Post & $\mathrm{N}$ & $\mathrm{R}^{2}$ \\
\hline Capex & $\begin{array}{r}0.006 \\
(0.834)\end{array}$ & 2,377 & 0.411 & $\begin{array}{l}-0.029^{* *} \\
(-2.478)\end{array}$ & 2,432 & 0.418 \\
\hline $\begin{array}{l}\text { R\&D } \\
\text { Expenses }\end{array}$ & $\begin{array}{r}-0.011 \\
(-1.614)\end{array}$ & 2,382 & 0.605 & $\begin{array}{r}0.009 \\
(0.941)\end{array}$ & 2,437 & 0.612 \\
\hline $\begin{array}{l}\text { Acquisition } \\
\text { Expenses }\end{array}$ & $\begin{array}{l}-0.073^{* * *} \\
(-2.851)\end{array}$ & 2,277 & 0.125 & $\begin{array}{r}-0.017 \\
(-0.836)\end{array}$ & 2,330 & 0.111 \\
\hline $\begin{array}{l}\text { Total } \\
\text { Investment }\end{array}$ & $\begin{array}{l}-0.072^{* *} \\
(-2.126)\end{array}$ & 2,275 & 0.244 & $\begin{array}{r}-0.049 \\
(-1.503)\end{array}$ & 2,328 & 0.2599 \\
\hline $\begin{array}{l}\text { Debt Issuance } \\
\text { (gross) }\end{array}$ & $\begin{array}{l}-0.135^{\text {*** }} \\
(-2.635)\end{array}$ & 2,287 & 0.121 & $\begin{array}{r}-0.042 \\
(-0.953)\end{array}$ & 2,341 & 0.123 \\
\hline $\begin{array}{l}\text { Equity } \\
\text { Issuance }\end{array}$ & $\begin{array}{r}-0.011 \\
(-0.478)\end{array}$ & 2,337 & 0.263 & $\begin{array}{l}-0.131^{* * *} \\
(-3.724)\end{array}$ & 2,399 & 0.297 \\
\hline $\begin{array}{l}\text { Total } \\
\text { Financing }\end{array}$ & $\begin{array}{l}-0.097^{* *} \\
(-2.354)\end{array}$ & 2,379 & 0.190 & $\begin{array}{l}-0.146^{* * *} \\
(-3.469)\end{array}$ & 2,434 & 0.221 \\
\hline $\begin{array}{l}\text { Cash } \\
\text { Dividends }\end{array}$ & $\begin{array}{c}0.003^{* * *} \\
(2.088)\end{array}$ & 2,359 & 0.218 & $\begin{array}{r}-0.005 \\
(-1.004)\end{array}$ & 2,413 & 0.179 \\
\hline $\begin{array}{l}\text { Cash } \\
\text { Position }\end{array}$ & $\begin{array}{r}-0.024 \\
(-1.176)\end{array}$ & 2,382 & 0.439 & $\begin{array}{l}-0.058^{* * *} \\
(-2.039)\end{array}$ & 2,437 & 0.456 \\
\hline
\end{tabular}

Table 4 reports the results of the estimation of the difference-in-differences model if we constrain our treatment sample to companies that established an investment banking relationship through a debt deal and an equity deal, respectively. Variables are defined in the notes of Table 3. Control variables are included but omitted for space reasons. All specifications include industry fixed effects. The values in parentheses represent $\mathrm{t}$-values based on standard errors clustered at the firm level. *** indicates significance at the $1 \%$ level, $* *$ indicates significance at the $5 \%$ level, and $*$ indicates significance at the $10 \%$ level. 
Table 5 Results of basic regression model for different affiliation periods

\begin{tabular}{|c|c|c|c|c|c|c|c|c|c|c|}
\hline $\begin{array}{c}\text { Affiliation } \\
\text { Period }\end{array}$ & $\begin{array}{c}\text { Regression } \\
\text { Specification }\end{array}$ & Capex & $\begin{array}{c}R \& D \\
\text { Expenses }\end{array}$ & $\begin{array}{c}\text { Acquisition } \\
\text { Expenses }\end{array}$ & $\begin{array}{c}\text { Total } \\
\text { Investment }\end{array}$ & $\begin{array}{c}\text { Debt Issuance } \\
\text { (gross) }\end{array}$ & $\begin{array}{c}\text { Equity } \\
\text { Issuance }\end{array}$ & $\begin{array}{c}\text { Total } \\
\text { Financing }\end{array}$ & $\begin{array}{c}\text { Cash } \\
\text { Dividends }\end{array}$ & $\begin{array}{c}\text { Cash } \\
\text { Holdings }\end{array}$ \\
\hline \multirow[t]{3}{*}{3 Years } & Treated*Post & $-0.015^{\text {** }}$ & 0.002 & $-0.047^{* * * *}$ & $-0.063^{* * *}$ & $-0.095^{* * * *}$ & $-0.074^{\text {***** }}$ & $-0.124^{* * * *}$ & -0.001 & $-0.037^{* *}$ \\
\hline & t-value & $(-2.065)$ & $(0.338)$ & $(-2.596)$ & $(-2.516)$ & $(-2.672)$ & $(-3.132)$ & $(-3.848)$ & $(-0.439)$ & $(-1.966)$ \\
\hline & $\mathrm{N}$ & 2,588 & 2,593 & 2,481 & 2,479 & 2,492 & 2,548 & 2,590 & 2,568 & 2,593 \\
\hline \multirow[t]{3}{*}{4 Years } & Treated*Post & -0.009 & 0.004 & -0.025 & -0.029 & $-0.060^{*}$ & $-0.040^{*}$ & $-0.073^{* * *}$ & -0.001 & -0.022 \\
\hline & t-value & $(-1.398)$ & $(0.64)$ & $(-1.477)$ & $(-1.250)$ & $(-1.840)$ & $(-1.866)$ & $(-2.454)$ & $(-0.440)$ & $(-1.284)$ \\
\hline & $\mathrm{N}$ & 2,670 & 2,675 & 2,560 & 2,558 & 2,570 & 2,629 & 2,672 & 2,647 & 2,675 \\
\hline \multirow[t]{3}{*}{5 Years } & Treated*Post & -0.004 & 0.006 & -0.016 & -0.012 & -0.030 & -0.027 & $-0.047^{*}$ & -0.001 & -0.013 \\
\hline & t-value & $(-0.763)$ & $(1.158)$ & $(-1.057)$ & $(-0.586)$ & $(-0.997)$ & $(-1.424)$ & $(-1.745)$ & $(-0.309)$ & $(-0.800)$ \\
\hline & $\mathrm{N}$ & 2,737 & 2,742 & 2,625 & 2,623 & 2,635 & 2,695 & 2,739 & 2,714 & 2,742 \\
\hline \multirow[t]{3}{*}{6 Years } & Treated*Post & -0.005 & 0.006 & -0.016 & -0.013 & -0.032 & -0.023 & $-0.046^{*}$ & -0.001 & -0.012 \\
\hline & t-value & $(-0.961)$ & (1.306) & $(-1.084)$ & $(-0.628)$ & $(-1.113)$ & $(-1.276)$ & $(-1.759)$ & $(-0.232)$ & $(-0.799)$ \\
\hline & $\mathrm{N}$ & 2,773 & 2,779 & 2,661 & 2,659 & 2,670 & 2,731 & 2,775 & 2,750 & 2,779 \\
\hline \multirow[t]{3}{*}{7 Years } & Treated*Post & -0.004 & 0.006 & -0.016 & -0.011 & -0.034 & -0.018 & -0.038 & -0.001 & -0.010 \\
\hline & $\mathrm{t}$-value & $(-0.710)$ & $(1.292)$ & $(-1.164)$ & $(-0.590)$ & $(-1.220)$ & $(-1.040)$ & $(-1.525)$ & $(-0.473)$ & $(-0.666)$ \\
\hline & $\mathrm{N}$ & 2,809 & 2,815 & 2,695 & 2,693 & 2,706 & 2,766 & 2,811 & 2,786 & 2,815 \\
\hline \multirow[t]{3}{*}{8 Years } & Treated*Post & -0.002 & 0.007 & -0.01 & -0.002 & -0.029 & -0.013 & -0.029 & -0.002 & -0.006 \\
\hline & t-value & $(-0.425)$ & $(1.547)$ & $(-0.755)$ & $(-0.124)$ & $(-1.090)$ & $(-0.815)$ & $(-1.180)$ & $(-0.892)$ & $(-0.447)$ \\
\hline & $\mathrm{N}$ & 2,838 & 2,844 & 2,723 & 2,721 & 2,735 & 2,795 & 2,840 & 2,815 & 2,844 \\
\hline \multirow[t]{3}{*}{9 Years } & Treated*Post & -0.002 & 0.007 & -0.009 & -0.000 & -0.025 & -0.011 & -0.022 & -0.002 & -0.008 \\
\hline & t-value & $(-0.331)$ & $(1.577)$ & $(-0.666)$ & $(-0.007)$ & $(-0.987)$ & $(-0.728)$ & $(-0.974)$ & $(-0.893)$ & $(-0.567)$ \\
\hline & $\mathrm{N}$ & 2,870 & 2,876 & 2,755 & 2,753 & 2,765 & 2,827 & 2,872 & 2,847 & 2,876 \\
\hline \multirow[t]{3}{*}{10 Years } & Treated*Post & -0.002 & $0.007^{*}$ & -0.007 & 0.001 & -0.024 & -0.009 & -0.020 & -0.002 & -0.004 \\
\hline & $\mathrm{t}$-value & $(-0.502)$ & $(1.724)$ & $(-0.592)$ & $(0.053)$ & $(-0.969)$ & $(-0.625)$ & $(-0.878)$ & $(-0.892)$ & $(-0.299)$ \\
\hline & $\mathrm{N}$ & 2,895 & 2,901 & 2,779 & 2,777 & 2,790 & 2,852 & 2,897 & 2,872 & 2,901 \\
\hline
\end{tabular}

Table 5 reports the results of the estimation of the difference-in-differences model with different affiliation periods used for the treatment assignment. Control variables are included but omitted for space reasons. Variables are defined in the notes of Table 3. Control variables are included but omitted for space reasons. All specifications include industry fixed effects. The values in parentheses represent $\mathrm{t}$-values based on standard errors clustered at the firm level. *** indicates significance at the $1 \%$ level, ** indicates significance at the $5 \%$ level, and * indicates significance at the $10 \%$ level. 
Table 6 Descriptive statistics and difference-in-differences results for matched samples

Panel A: Descriptive statistics for matching variables

Full Sample

\begin{tabular}{cc} 
Full Sample \\
\hline Treated $\quad$ Control Difference
\end{tabular}

Size

Tobin's Q

Sales Growth

Return on Assets (ROA)

Age
7.29

2.31

1.29

0.11

12.28
6.83

$0.46^{* * *}$

2.01

1.20

0.11

13.61
$0.30^{* * *}$

$0.09^{* *}$

0.00

$-1.33^{* * *}$
Matched Sample

Treated Control Difference

Panel B: Difference-in-differences estimations using matched sample

\begin{tabular}{|c|c|c|c|}
\hline & Treated*Post & $\mathrm{N}$ & $\mathrm{R}^{2}$ \\
\hline Capex & $\begin{array}{c}-0.019^{*} \\
(-1.921)\end{array}$ & 769 & 0.361 \\
\hline $\mathrm{R} \& \mathrm{D}$ & -0.009 & 770 & 0.333 \\
\hline Expenses & $(-1.124)$ & & \\
\hline Acquisition & $-0.047^{* *}$ & 736 & 0.097 \\
\hline Expenses & $(-2.018)$ & & \\
\hline Total & $-0.107^{* * *}$ & 735 & 0.196 \\
\hline Investment & $(-2.627)$ & & \\
\hline Debt Issue & $-0.113^{* *}$ & 749 & 0.171 \\
\hline (gross) & $(-2.109)$ & & \\
\hline Equity & $-0.148^{* *}$ & 758 & 0.105 \\
\hline Issuance & $(-2.302)$ & & \\
\hline Total & $-0.160^{* *}$ & 770 & 0.129 \\
\hline Financing & $(-2.315)$ & & \\
\hline Cash & -0.002 & 762 & 0.176 \\
\hline Dividends & $(-0.494)$ & & \\
\hline Cash & -0.054 & 770 & 0.230 \\
\hline Holdings & $(-1.472)$ & & \\
\hline
\end{tabular}

Table 6 reports descriptive statistics (Panel A) and the results of the estimation of the difference-in-differences model (Panel B) for a sample consisting of treated companies and a matched control sample. Control variables are included but omitted for space reasons. Variables are defined in the notes of Table 3. Sales Growth is defined as a firm's sales in year $t$ divided by a firm's sales in year $t$ (Compustat item sale). Return on Assets (ROA) is defined as a firm's operating income before depreciation (Compustat item oibdp) divided by a firm's lagged total assets (Compustat item at). Control variables are included but omitted for space reasons. All specifications include industry fixed effects. The values in parentheses represent t-values based on standard errors clustered at the firm level. $* * *$ indicates significance at the $1 \%$ level, $* *$ indicates significance at the $5 \%$ level, and * indicates significance at the $10 \%$ level. 
Table 7 Results for separated regression model using firm-fixed effects

\begin{tabular}{|c|c|c|c|c|c|c|c|}
\hline \multirow{3}{*}{$\begin{array}{l}\text { Dependent } \\
\text { Variable } \\
\text { Capex }\end{array}$} & \multicolumn{3}{|c|}{ Panel A: Treated Firms } & \multicolumn{3}{|c|}{ Panel B: Control Firms } & \multirow[b]{2}{*}{ Test } \\
\hline & Post & $\mathrm{N}$ & $\mathrm{R}^{2}$ & Post & $\mathrm{N}$ & $\mathrm{R}^{2}$ & \\
\hline & $\begin{array}{l}-0.044 \text { *** } \\
(-5.487)\end{array}$ & 375 & 0.808 & $\begin{array}{l}-0.030 \text { *** } \\
(-11.046)\end{array}$ & 2,212 & 0.810 & $0.062^{*}$ \\
\hline $\begin{array}{l}\text { R\&D } \\
\text { Expenses }\end{array}$ & $\begin{array}{r}-0.002 \\
(-0.339)\end{array}$ & 375 & 0.938 & $\begin{array}{l}-0.003 * * \\
(-2.451)\end{array}$ & 2,218 & 0.961 & 0.748 \\
\hline $\begin{array}{l}\text { Acquisition } \\
\text { Expenses }\end{array}$ & $\begin{array}{l}-0.076 * * * \\
(-3.713)\end{array}$ & 363 & 0.593 & $\begin{array}{l}-0.032 * * * \\
(-6.055)\end{array}$ & 2,118 & 0.591 & $0.021^{* *}$ \\
\hline $\begin{array}{l}\text { Total } \\
\text { Investment }\end{array}$ & $\begin{array}{l}-0.136 \text { *** } \\
(-4.979)\end{array}$ & 363 & 0.648 & $\begin{array}{l}-0.072 * * * \\
(-9.830)\end{array}$ & 2,116 & 0.704 & $0.017^{* *}$ \\
\hline $\begin{array}{l}\text { Debt Issuance } \\
\text { (gross) }\end{array}$ & $\begin{array}{l}-0.138 \text { *** } \\
(-3.320)\end{array}$ & 365 & 0.621 & $\begin{array}{l}-0.062 \text { *** } \\
(-6.157)\end{array}$ & 2,127 & 0.775 & $0.043^{* *}$ \\
\hline $\begin{array}{l}\text { Equity } \\
\text { Issuance }\end{array}$ & $\begin{array}{l}-0.088 * * * \\
(-3.403)\end{array}$ & 368 & 0.653 & $\begin{array}{l}-0.025 * * * \\
(-3.812)\end{array}$ & 2,180 & 0.683 & $0.009^{* * * *}$ \\
\hline $\begin{array}{l}\text { Total } \\
\text { Financing }\end{array}$ & $\begin{array}{l}-0.174 * * * \\
(-5.093)\end{array}$ & 375 & 0.682 & $\begin{array}{l}-0.055 * * * \\
(-5.771)\end{array}$ & 2,215 & 0.657 & $0.000^{* * *}$ \\
\hline $\begin{array}{l}\text { Cash } \\
\text { Dividends }\end{array}$ & $\begin{array}{r}-0.003 \\
(-1.243)\end{array}$ & 372 & 0.756 & $\begin{array}{r}-0.001 \\
(-1.350)\end{array}$ & 2,196 & 0.768 & 0.477 \\
\hline $\begin{array}{l}\text { Cash } \\
\text { Holdings }\end{array}$ & $\begin{array}{l}-0.043 * * \\
(-2.461)\end{array}$ & 375 & 0.901 & $\begin{array}{r}0.001 \\
(0.207)\end{array}$ & 2,218 & 0.887 & $0.007^{* * *}$ \\
\hline
\end{tabular}

Table 7 reports the results of the estimation of the difference-in-differences model for the subsample of treated (Panel A) and control (Panel B) firms. In addition to our set of (unreported) control variables (see Table 3), we add firm-fixed effects. Post denotes the difference in the dependent variable from the pre-crash period to the post-crash period. Test denotes the p-value of a Chow (1960) test, testing the inequality of the post variable between the two regressions for treated and untreated firms. Variables are defined in the notes of Table 3. Control variables are included but omitted for space reasons. The values in parentheses represent t-values. *** indicates significance at the $1 \%$ level, ** indicates significance at the $5 \%$ level, and * indicates significance at the $10 \%$ level. 
Table 8 Results for separated regression comparing client effects from different investmet banks

\begin{tabular}{|c|c|c|c|c|c|c|}
\hline \multirow{2}{*}{$\begin{array}{l}\text { Dependent } \\
\text { Variable }\end{array}$} & \multicolumn{3}{|c|}{$\begin{array}{c}\text { Panel A: } \\
\text { Clients of LB }\end{array}$} & \multicolumn{3}{|c|}{$\begin{array}{c}\text { Panel B: } \\
\text { Clients of ML and BS }\end{array}$} \\
\hline & Treated*Post & $\mathrm{N}$ & $\mathrm{R}^{2}$ & Treated*Post & $\mathrm{N}$ & $\mathrm{R}^{2}$ \\
\hline Capex & $\begin{array}{l}-0.021^{* *} \\
(-1.971)\end{array}$ & 2,382 & 0.418 & $\begin{array}{r}-0.009 \\
(-1.031)\end{array}$ & 2,419 & 0.413 \\
\hline$R \& D$ & 0.000 & 2,387 & 0.605 & 0.003 & 2,424 & 0.609 \\
\hline Expenses & $(0.016)$ & & & $(0.334)$ & & \\
\hline Acquisition & $-0.051^{* *}$ & 2,284 & 0.115 & $-0.042^{*}$ & 2,315 & 0.116 \\
\hline Expenses & $(-2.069)$ & & & $(-1.773)$ & & \\
\hline $\begin{array}{l}\text { Total } \\
\text { Investment }\end{array}$ & $\begin{array}{l}-0.080^{* *} \\
(-2.443)\end{array}$ & 2,282 & 0.248 & $\begin{array}{r}-0.047 \\
(-1.382)\end{array}$ & 2,313 & 0.241 \\
\hline $\begin{array}{l}\text { Debt Issue } \\
\text { (gross) }\end{array}$ & $\begin{array}{l}-0.132^{* *} \\
(-2.497)\end{array}$ & 2,291 & 0.130 & $\begin{array}{r}-0.064 \\
(-1.403)\end{array}$ & 2,382 & 0.118 \\
\hline $\begin{array}{l}\text { Equity } \\
\text { Issuance }\end{array}$ & $\begin{array}{l}-0.085^{* * *} \\
(-2.821)\end{array}$ & 2,346 & 0.269 & $\begin{array}{r}-0.063^{*} \\
(-1.848)\end{array}$ & 2,382 & 0.271 \\
\hline $\begin{array}{l}\text { Total } \\
\text { Financing }\end{array}$ & $\begin{array}{l}-0.134^{* * *} \\
(-3.425)\end{array}$ & 2,384 & 0.193 & $\begin{array}{c}-0.114^{\text {** }} \\
(-2.409)\end{array}$ & 2,421 & 0.206 \\
\hline $\begin{array}{l}\text { Cash } \\
\text { Dividends }\end{array}$ & $\begin{array}{r}-0.001 \\
(-0.372)\end{array}$ & 2,363 & 0.184 & $\begin{array}{r}-0.001 \\
(-0302)\end{array}$ & 2,401 & 0.213 \\
\hline $\begin{array}{l}\text { Cash } \\
\text { Holdings }\end{array}$ & $\begin{array}{r}-0.028 \\
(-1.313)\end{array}$ & 2,387 & 0.456 & $\begin{array}{r}-0.044 \\
(-1.547)\end{array}$ & 2,424 & 0.452 \\
\hline
\end{tabular}

Table 8 reports the results of the estimation of the difference-in-differences model for the sub-sample of clients of Lehman Brothers (LB) (Panel A) and clients of Merrill Lynch (ML) and Bear Stearns (BS) (Panel B). Variables are defined in the notes of Table 3. Control variables are included but omitted for space reasons. The values in parentheses represent $\mathrm{t}$-values based on standard errors clustered at the firm level. *** indicates significance at the $1 \%$ level, $* *$ indicates significance at the $5 \%$ level, and $*$ indicates significance at the $10 \%$ level. 